Rethinking non-traditional resistance at work: the case of the Indian Diaspora in Mauritius.

Pratima Sambajee*

Strategy and Organisation, University of Strathclyde, Glasgow, UK

Strathclyde Business School, Level 7, Livingstone Tower, 26 Richmond Street, Glasgow, G1 1XH

*Email:pratima.sambajee@ strath.ac.uk 


\title{
Rethinking non-traditional resistance at work: the case of the Indian Diaspora in Mauritius
}

\author{
Resistance at work can take many forms and be theorised in multiple ways. In \\ this paper, I use postcolonial theorist, Homi Bhabha's concepts of mimicry, \\ ambivalence and hybridity to explore non-traditional forms of resistance among \\ Indo-Mauritians working in the hotel industry. I employ a two-stage qualitative \\ research approach by conducting focus groups in eight hotels in Mauritius \\ followed by focused ethnography with twenty Indo-Mauritians. The findings \\ reveal that the Indian diasporic community is actively engaging with its past \\ (India) through the materiality of its home, its sacred space, and its use of \\ Bhojpuri to communicate. By unfolding and maintaining its difference, it is \\ constantly demarcating its personal space from that of the Other. As this \\ behaviour extends to the workplace, salient forms of non-traditional resistance \\ surface in rural regions.
}

Keywords: Indian Diaspora; resistance; mimicry; ambivalence; hybridity; Mauritius

\section{Introduction}

The overseas Indian community is estimated to around 25 million spread across 70 countries around the world. In its 2012-2013 annual report, the Ministry of Overseas Indian Affairs used terms such as non-resident Indians (NRIs), persons of Indian origin (PIOs) and Indian Diaspora to describe this population. All three denote a compulsory connection with India either through holding an Indian passport or ancestral roots. However, linking the term 'Diaspora' to this population has key implications. Along with being a population residing away from its land of origin, a Diaspora is usually characterised by strong retention of group ties and practices over a period of time; a perseverance of a myth of and strong connections to a homeland (Ralph and Staeheli 2011; Tölölyan 2010). As a result, identifications of roots, routes and the new home are concomitant in theories of Diaspora. In India's case, Jain (2010) distinguished between the 'old' and the 'new' Diaspora. The former emerged from Indian emigration which took place in the early eighteenth century under the British colonial system. The 'old' 
Diaspora can be found in Fiji, Mauritius, Suriname, Guyana, Trinidad and East Africa. The 'new' Diaspora, on the other hand, includes more recent movements of highly skilled educated Indian workers and students to developed countries such as the USA, UK, Canada, Australia and New Zealand; and the movement of unskilled and semiskilled workers to the Gulf countries and Malaysia (see,e.g; Pandey et al [2004, 2] for a summary). There is evidence that in the case of the Indian Diaspora, an Indian homeland has existed continuously (Bhatia and Ram 2009; Raj 2012; Safran 2009). Existing studies have brought to the front how the Diaspora has maintained its culture while living away from home but understanding the extent to which this persistence influences workplace dynamics has been neglected.

Fields of research closest to the hermeneutics of Diaspora and workplace behaviour include studies on expatriate management (Cole and Nesbeth 2014; Lazarova et al. 2010; Lee 2013; Srivastava and Panday 2012) and international migration (Beine et al. 2011; Beine and Salomone 2013; Kapur 2014). Research on Diaspora knowledge networks (Meyer, 2001), scientific Diaspora networks (Barre et al. 2003; Meyer 2001; Tejada et al. 2013), and Diaspora inward and outward foreign direct investment (Javorcik 2011; Vaaler 2013), denote an increased acknowledgement of the need to understand Diasporas' dynamics in both home and host countries. In context of the Indian Diaspora, existing studies have focussed on foreign investment (Anwar and Mughal 2013; Buckley et al. 2012; Contractor et al. 2015; Tung et al. 2011), knowledge transfer within the Information Technology and Software sectors (Dhume 2002; Kapur 2001; Pandey et al. 2004; Pande 2014; Saxenian 1999), home-making of expatriate female Indians (Panday and Srivastava 2012) and Diaspora entrepreneurship (Chand 2012; Vemuri 2014). While these concentrated on the 'new' Diaspora, studies on the first wave of Indian emigration have in part or wholly concentrated on the relationship between the homeland and identity (Dickinson 2015; Premdas 2011; Sinha 2014), consumption of symbolic goods and material continuities (Sambajee 2011; Sinha 2014), religion and ethnicity (Eisenlohr 2013; Kumar 2012; Lal 2015; Vertovec 2000), gender (Hiralal 2014; Raghunandan 2012) and cultural behaviours (Eisenlohr 2013; Sinha 2014). These studies suggest that maintaining a connection with India has never ceased to be a fundamental feature of this diasporic community despite generations from leaving India. In this paper, I argue that the Diaspora's continued connections with the homeland also influences its behaviour at work. To conceptualise these connections, I 
will depart from the Diaspora's home as Bhabha (1994) stated that this is where visions of community emerge.

Existing research on Indians and Indian culture at work found that Indians adopt situational and context-sensitive behaviours (see: Panda and Gupta 2012; Sinha 2002, 2004; Sinha and Kanungo 1997; Sinha and Pandey 2007), display moderately collectivist characteristics (see: Hofstede 1980; Sinha and Sinha 1990; The Globe study 2002), attach great importance to personalised relationship and family (see: Sinha 2000, 2002, 2004; Sinha and Pandey 2007; Sinha and Sinha 1990; Suri and Abott 2013), display strong religious and spiritual orientations (Sinha et al. 2003), display individualist traits when dealing with out-group members (Sinha 2000; Suri and Abott 2013), are materialistic when working in international organisations and adopt holistic behaviours by integrating both work and people orientations in organisations (Sinha and Pandey 2007). These studies have been formidable in constructing theories and models describing Indian culture in the organisational context but do these traits and characteristics persist as people of Indian origin move to live and work on new lands such as Mauritius? Should manifestations of culture in organisations be solely explained by the nation as the surrogate? Moreover, the above theories have certainly overlooked an essential characteristic of the context: the unequal power relations in India's postcolonial present. Scott (1985) argued that resistance is an unavoidable weapon of the weak in such hegemonic situations. Similarly Prasad and Prasad (2001) stated that many of the routine and mundane behaviours and practices within postcolonial contexts can represent altered characters of resistance. If this is the case, could the above findings on Indians and Indian culture in organisations be masking conscious and unconscious non-traditional forms of resistance?

Mauritius is similar to India by virtue of its colonial history and current postcolonial context. Therefore, alongside exploring the home of its Indian Diaspora, an important aim of this paper is to capture those routine, mundane behaviours which have the potential of revealing non-traditional forms of resistance. To achieve this, a framework capable of theorizing beyond conventional accounts of resistance is required (see Bhabha 1994; Kalonaityte 2010; Mir et al. 2003; Prasad 2003; Spivak 1999, 2008). In this paper, I will deploy postcolonial theorist, Bhabha's concepts of mimicry, ambivalence and hybridity to theorise non-traditional resistance at work within the 
Diaspora. The remaining paper is structured as follows: I begin by describing the Indian Diaspora in Mauritius and existing research carried out on them. This is followed by the theoretical framework where I discuss the suitability of Bhabha's concepts of mimicry, ambivalence and hybridity for my research. I then describe the methodology used followed by a presentation and discussion of the findings and finally, the concluding remarks.

\section{The Indian Diaspora in Mauritius}

Mauritius is an island in the Indian Ocean populated by both French and British colonization in the early eighteenth century. Indian indentured labourers were brought by the British to meet the labour needs in this sugar-growing colony. Although the initial contract was for five years, after which they could return to India, only one third returned (Deerpalsing 2002). Through both colonial systems, African slaves and Chinese petty merchants were also brought to the island. African slaves first arrived through French colonisation. As Britain took over in 1810, the Act of Capitulation handing over the island to them stated that the inhabitants could retain their religion, customs, property, and laws. Furthermore the 1814 Treaty of Paris reinforced this by demanding that the population was to keep its language, its religion and its laws which existed under French rule. Hence, French and a French-based Creole (Kreol) continued to be spoken under British rule. Indentured Indians came from Uttar Pradesh, South India while the Marathi immigrants came from the provinces of Ratnagari, Savantvadi, Satara, Malvanand and Thane. They spoke mainly Bhojpuri which is a dialect of Hindi widely spoken in the western parts of Bihar and the eastern parts of Uttar Pradesh (UP). Upon their arrival, Mauritius underwent both a demographic and linguistic revolution. In addition to French, English and Kreol, Bhojpuri, Gujarati, Marathi, Tamil, Telugu, Hindi and Urdu became part of the Mauritian soundscape (Miles, 1999). The most recent 2011 Census statistics show that the population of Mauritius is approximately 1.2 million with two-thirds of Indian origin, followed by those of African descent (Creoles) and Chinese origin. Religion wise, fifty-two percent are Hindus, thirty-two percent are (Catholic) Christians, sixteen percent are Muslims, and the remainder is Sikh and Bahai.

Currently, the context is representational of the institutional practices that enabled the colonizers to manage the island politically and sociologically pre- 
independence. For example, the divide and rule strategy of British colonialism which was politically endorsed since 1968. Mauritius adopted a constitution whereby elections are by the First-Past-the-Post System (FPTP) but with elements that promote a powersharing democracy such as a multi-member constituency, electoral districts and the Best Loser System for underrepresented minorities. Since then the political system has greatly influenced Mauritian society to become highly ethnicised (Jahangeer-Chojoo 2010). Despite economic development and the adoption of a common globalised lifestyle, the symbolic dimensions of ethnic groups based on race, religion and ancestral language has gained more relevance and national identity has not developed (see Callikan 2001; Jahangeer-Chojoo 2010; Owodally and Mooznah 2011). Further studies found that Mauritians support ethnic and class-based ideologies and nationalism is only possible if it does not interfere with 'ethnic identities' (see: Boswell 2005, Caroll and Caroll 2000; Eriksen 1990, 1994). Eriksen blamed successive governments to have deepened these ethnic differences by instating cultural centres for each ethnic group instead of national institutions. Another resulting aftermath of colonialism is the dominant use of French and English languages in education, work and all administrative affairs to the detriment of native dialects such as Kreol and Bhojpuri (Rajah-Carrim 2005). In 2012, the government introduced Kreol in schools but its low status vis-à-vis French and English remains. As for Bhojpuri, it is inexistent in the school curriculum or in any other formal encounters and the 2011 census reported only $5 \%$ of the population speaking the dialect compared to $12 \%$ in 2000.

The possible areas of inquiry on the Indian Diaspora in such a multi-lingual, multi-cultural and multi-ethnic context are legion. Some studies have focused largely on language (see: Bissoonauth 2011; Eisenlohr 2011; Eriksen 1990; Owodally 2011; Rohatgi 2013). They all described it is a marker of ethnicity for Mauritian Hindus. Others found that caste (see: Hollup 1994; Kasenally 2011; Sen 2014), ethnic endogamy (Nave 2000), political power (see: Hirschmann 2014; Hollup 1994; Mathur 2012), religion (see: Eisenlohr 2010, 2011; 2013; Mulloo 2007) and culture (see: Carter and Torabully 2002; Deerpalsing 2002; Eisenloh, 2013, Tseug-Wong 2015) were dominant strategies used by the Indian Diaspora to maintain its own distinctive culture and ethnicity. While these studies have significantly contributed to our understanding of the Diaspora's cultural dimensions, they lack a theoretical lens capable of identifying unequal power relations experienced by the Diaspora in this postcolonial context. They 
have also overlooked the forms of resistance engendered by these inequalities in other fields of life, such as the workplace. The aim of this paper is to address this.

\section{Theorising resistance through a postcolonial lens}

My focus on understanding the Diaspora's cultural dimensions in the realm of postcolonial discourse and translating its cultural behaviours as forms of resistance merits the use of a theoretical lens whose epistemological perspective can exert constant pressure on and reorient the logics and trajectories of traditional scholarship. Both Bhabha (1994) and Prasad (2012) advanced that postcolonial theory is able to theorise this way. In the study of organisations, the theory suggests that certain relations are informed by the idea of Europe and are marked by boundaries between the supposedly superior and inferior. Its two key tasks are first to analyse colonial discourses and second to theorize non-binary and non-western models of thought, agency and resistance (Kalonaityte 2010; Prasad 2012). As mentioned earlier, of interest to this paper is the concept of resistance and more specifically non-traditional resistance. Adopting a postcolonial lens therefore renders this possible.

However Young (2008) argued that it is difficult to determine a general postcolonial theory. Edward Said's (1977) seminal work titled Orientalism laid the foundation for various postcolonial critics including Bhabha. In Orientalism, Said discusses the hegemony between the Orient (The East) and the Occident (The West or more specifically British and French cultural enter-prises). The Occident is seen to have a relationship of power and domination over the Orient and the presence of the West in the aftermath of colonisation is expressed and represented by the persistence of supporting institutions, colonial bureaucracies and colonial styles. Said was among the first of postcolonial critics to scrutinize colonialism's discursive practices; he brought to light the rhetorical and representational schemes through which the West constructed and manipulated the representations of the Orient to imperialist ends. Said also used the term 'imagined geographies' to describe how the West endowed the material dimension of space with cultural meanings in an attempt to demarcate space that is 'ours' and 'theirs'. The setting up of such boundaries becomes an ideological impulse of the dominant group to control place and people. However, Said was faulted for binary thinking and Homi Bhabha was one of the earliest scholars to have criticized Said's assessment of colonial discourse and power. 


\section{Mimicry, ambivalence and hybridity}

Bhabha (1990) acknowledged the pedagogical narrative informed by the idea that the West was morally and intellectually superior but also considered people as more than historical events capable of resisting the homogenising intent of the coloniser through various non-traditional forms. He described two interconnected analytical concepts to decode and represent non-traditional resistance: pedagogical and performative temporalities, both described as two different moments, the past and the present. The first one takes on a linear national narrative whereby linear chronological histories are used as instruments of national identity. Through performativity, people are able to resist the pedagogical. As stated by Bhabha, "it disturbs those ideological manoeuvres though which [imagined communities] are given essentialist identities" (1994, 149, emphasis in text). Two effects of the performative narrative is that on one hand it leads to the search of new boundaries and invention of new national symbol to maintain hierarchical relations between cultures and on the other hand it subverts the notion of cultural purity. Bhabha used the French word mise en scene to describe the performative temporality as the staging of cultural difference through a set of actions for example political, religious, and commercial. The usefulness of performativity is that it allows the unfolding of narratives from those who are obscured by the nation's pedagogical narrative and gives a voice to minority and obscured groups.

One form of performative narrative is mimicry. It has a dual strategy. On the one hand, it is described as the process through which the coloniser attempts to force the colonised to act like them so as to make the unfamiliar familiar to facilitate colonial domination. On the other, it highlights the difference in knowledge between the colonised and coloniser thus forcing the former to import from the latter. The situation where non-westerners use national symbols to imitate the cultural capital of the West is a typical illustration. Mimicry in postcolonial discourse emerges as a representation of difference with a desire for a reformed and recognisable Other but where the desire for authenticity becomes a final irony of partial representation only that is "a subject of a difference, that is almost the same, but not quite the same" (Bhabha 1984, 126). The colonised repeats rather than represents and colonial authority has partial presence, both incomplete and virtual. Özkazanç-Pan (2008) argues that mimicry produces a space of resistance which destabilises and undermines colonial authority. Moreover Bhabha (1994) and Ashcroft et al (1995) highlighted that this space is highly contested, unstable 
and is always present at the site of colonial dominance. In it, positions and feelings of in-betweenness prevail to resume to a third space as stipulated by Bhabha. Pal and Dutta (2008) added that this space is accompanied by ambivalence which represents the empowering intentions of the colonizer. As Bhabha pointed out "the discourse of mimicry is constructed around an [ambivalence]: in order to be effective, mimicry must continually produce its slippage, its excess, its difference" (1984, 126, emphasis in text). It is within this ambivalent space that the monolithic discourse of colonisation is ruptured to reveal the cracks and fissures for potential resistance. Both ambivalence and mimicry create this double vision which menaces the authority of the dominant cultural imperatives. The virtual presence of the West can be discerned through the erratic and accidental objets trouves ${ }^{2}$ of colonial discourse also known as the part objects of presence (Bhabha 1984). The ambivalent space within which mimicry occurs represents a type of ongoing resistance to the dominant culture and serves to dismantle oppressive discourses (Kalonaityte 2010).

In The Location of Culture Bhabha claimed that cultural production is most productive where there is most ambivalence. He argued that the third space opens the possibility of hybrid spaces able to hold different identities together without entertaining "differences without assumed or imposed hierarchy" (1994, 4). Bhabha used hybridity to investigate the situation of colonialism. He described hybridity as a stairwell with temporal movements and passages which prevent identities from settling. Pal and Dutta also added that similar to mimicry, it is a process of cultural assimilation that is never complete. Thus, hybridity is the outcome of ambivalence and transforms both the colonised and colonizers. For the colonised, hybridity allows them to find their voice in a dialectic that does not seek cultural supremacy or sovereignty. Bhabha (1996) stated that they deploy partial culture from which they emerge to construct visions of community, and versions of historic memory, that give narrative form to the minority positions they occupy. On the other hand, Loomba (1998) argued that for the coloniser, hybridity is a menace as it destabilises hierarchical relations of power and purity, creating a space that lies outside binary oppositions and offers a potential site for resistance and autonomy. It causes the nature of colonial power to be questioned and

\footnotetext{
${ }^{2}$ Found objects
} 
displaced. Bhabha added that while ambivalence marks the lives of all colonials, hybridity adds to its intensity and subverts the notion of cultural purity. In linguistics, Bakhtin (1981) distinguished between intentional and organic hybridity. The former is used for a situation where one entity is able to consciously ironize and unmask the other where both entities carry on existing in the same context but where one entity, usually the dominant one loses its authority over the other. Borrowing from this, Bhabha applies the concept of intentional hybridity in colonial discourse to illustrate how hybridity "reverses the effects of the colonist disavowal, so that the other 'denied' knowledge enter upon the dominant discourse and estrange the basis of its authority" (1994, 156, emphasis in text). Intentional or conscious hybridity produces a contested situation where entities operate against each other. On the other hand, organic hybridity refers to the unconscious mixing of two entities to produce fusion where the fusion is "mute and opaque, never making use of conscious contrasts and oppositions" (Bakhtin, 1981: 360). Young (1995) added that this unconscious or organic hybridity gives birth to new forms of amalgamation rather than contestation. In postcolonial discourse, it is not simply adding here to there, but rather it is embedded in power and serves to understand and identify resistance. By discerning the layering of cultures (that of the coloniser and colonised), hybridity allows the postcolonial reader to identify new and creolised forms and/or forms that juxtaposed against each other. Both of which can be classified as nontraditional forms of resistance.

Pedagogical narratives of Mauritius are dominated by both French and British colonial footprints. Ironically, the instruments of national identity in Mauritius are all representatives of its colonial past for example its national anthem sung in both French and English; its school curriculum emphasising the importance of both languages as compulsory and essential to succeed: English and French names for schools, streets, towns, hospitals, tourist attractions, hotels and many more, and use of French and English in most administrative affairs. These remains of colonial presence constantly undermine the existence of the Other, at home, at work and in wider society. As previous researchers have found, Mauritian national identity has failed to develop due to the pedagogical success of maintaining French and English, political and institutional activity lobbying for ethnic separatedness. My paper builds upon the premise that the behaviours of individuals who live in such a context are contested and subject to unequal power relations across different spheres of life including at home and in the 
workplace. In order to capture these behaviours, a closer analysis of performativity both at home and at work is required. I now present my research process, followed by an analysis of the data to illustrate my arguments.

\section{The research study}

The data I am presenting in this paper comes from a set of twenty in-depth interviews with hotel employees, two interviews with Human Resource managers from two of these hotels and field notes written from observations. The former sample was selected from forty-eight participants who took part in eight focus groups conducted across eight hotels located on both rural and urban coasts of Mauritius. The initial sample of fortyeight employees ranged from different work positions, departments and ethnicities (see Table 1). At the onset, the aim of this research was to investigate employee mobility in the hotel industry. The focus groups were used to explore types of movement and factors influencing movement of employees. Amid several industry-specific findings (which will not be discussed in this paper), a discernible one was the low job mobility (upward movement along the organisational ladder) of Indo-Mauritians in rural regions. Given the multi-ethnic nature of the workforce and my focus on identifying unequal power relations, I decided to further investigate the disadvantaged position of these individuals.

\section{Table 1 Details of Participants}

Therefore, in the second stage of the research, theoretical sampling was used to identify participants who a) were Indo-Mauritians, b) had experienced both limited and some kind of movement along the organisational ladder during employment, c) occupied both skilled and low-skilled positions and d) had been in service for over a year. This resulted in a sample of twenty participants (italicised in Table 1). By using this sampling method, Strauss and Corbin (2008) stated that theoretical elaboration can be achieved. Weller and Romney (1988) also added that this method often leads to a small sample, representing a special population that needs a more fine-grained qualitative exploration in terms of specific beliefs, behaviour, or relevance to the larger group, without the need to increase the actual sample size. The next challenge was to choose a method that would a) be sufficiently sensitive to motivate participants to voice out actual causes of unequal job mobility, b) allow causes of nuances between rural and 
urban participants to emerge, c) give considerable attention to ethnic and cultural dimensions and d) make non-traditional forms on resistance recognisable.

In order to achieve these, an ethnographic approach was deemed most appropriate. Mitchell (2007) stated that ethnography by definition is about writing culture. Ybema et al (2009) added that its participant-centred and multi-vocal approach captures contextual insights and is rooted in the description of culture. Moreover, Imas and Weston (2012) confirmed that ethnography is useful when conducting research in non-western contexts as it is sensitive to local culture and historical experiences. However they also claimed that this methodology is often lengthy. To offset this, Knoblauch's (2009) focused ethnography was chosen as it allowed ethnographic research to be conducted in a restricted timescale. Hence, over a period of four months, I visited each participant in his/her home, conducted in-depth interviews, observed and wrote field notes on the participants' way of living. Participants were questioned on their acquaintances, networks, access to job information and language used at work. Using the residences of participants to conduct the interviews made them feel more comfortable to discuss sensitive work-related matters. Parallel interviews were also conducted with two Human Resource managers in order to explore the employer/organisational perspective. The use of multiple methods and multiple sources were driven by Bryman's (2004) claim that such an approach improved the reliability, robustness and rigor of the data.

\section{My analytic process}

Interviews from participants, Human Resource managers and field notes were analysed independently. In each, themes which had the potential of showing a) actual causes of unequal job mobility, b) causes of nuances between rural and urban participants, c) ethnic and cultural dimensions and d) non-traditional forms on resistance, were identified. Themes from all three sources were them brought together, compared and contrasted. Weller and Romney stated that this approach was necessary to observe consensus or variation from consensus in the data from multiple sources. This would also offset the limitations of using a small sample. Hence, this final thematic analysis lead to both evidence of consensus and variations between rural and urban regions. In the former's case, non-traditional forms of resistance both at home and at work emerged 
to counteract the homogenising intent of the Other. On the other hand, in urban regions, participants had embraced more hybrid forms of engagement.

Overall, the analysis shows that non-traditional forms of resistance at work were deeply rooted in the Diaspora's continued connections with its Indian roots which were initially manifested at home. Hence, in the next section, I start describing my findings by departing from its home to show how it is actively recreating visions of a faraway home via material forms, religion and language. The nuances between the rural and urban homes become clearly visible at this stage. By understanding the Diaspora's way of living through these home-making practices, it became possible to identify Diaspora consciousness at work.

\section{Home away from Home}

The material dimensions of the Diaspora's home were endowed with imaginative geographies of a traditional Hindu (Indian) household. Its home-making practices evoked emotions and memories beyond mundane possessions. These were captured in the material forms, religious rituals and use of Bhojpuri to communicate.

\section{Material cultures and engendered practices}

A prominent presence of traditional Indian kitchen utensils, tools and religious material forms were found in all homes visited. They were required to complete the landscape of a traditional Hindu home and Hindu culture as imagined by the Diaspora. Their repeated and active uses for specific occasions and rituals were narrated with enthusiasm by participants, symbolising strong attachment to these material forms:

I did not get much from my parents because when my mother married my father, he was an orphan. So he did not have anything, my mother did not have either, so I did not have it. But when I got married, they bought a $\operatorname{lota}^{l}$ and $\operatorname{thali}^{2}$ and gave me. I use the lota during Durga pooja ${ }^{3}$ and the thali when I do aarti $^{4}$ when I pray. I also bought my own dekchi ${ }^{5}, k a r a i^{6}$ and so on.

The authenticity of these material forms was difficult to trace as they were either inherited from earlier generations or bought from local shops. Nevertheless, as Dudley (2011) argues, the Diaspora's dependence on them (both physically and 
psychologically) evoked an essence of home-making whereby these objects of the past (or symbolising the past) had become powerful ways of forming and re-forming connections with this past. Their presence also engendered a series of practices and customs considered as Hindu. For example, the regular consumption of traditional Indian food, use of traditional Indian spices, vegetarianism and eating with the hand. Majority of the rural participants claimed that they preferred to eat with their hand as they were told by their elders that it was the Hindu way of eating. Some stated that they eat in a thali which was either made of stainless steel or copper. The latter, being the most traditional one, had been passed on from earlier generations and eating in it provided the satisfaction of also fulfilling the desires of the elders:

Me and my wife we eat in a thali, whereas the children eat in plates. For example, for me the reason I eat in a thali is because I want to keep my traditions. I eat in a copper thali and not the ordinary steel ones. I have this thali from my father. I had it cleaned when he gave it to me. When my children see it, they all want to eat in it because it is clean. We have to give them to show them our culture. In my house, everyone eats with the hand. We rarely use the spoon or fork.

Participants usually drank from a gilasa $a^{7}$ instead of a normal glass. The latter was only used for fizzy and more modern drinks. Participants were unable to justify this differential association:

If I have juice, I will have it in a gilasa but if I have coke or pepsi, I will have it in a glass.

I don't know, it is hard to tell. If I have a guest who is a bit religious, I will serve the person in a gilasa.

Many of the Diaspora's eating habits were imagined as Hindu. The following quote describes how eating with the hand in a thali and/or drinking from a gilasa becomes automatically associated with vegetarianism, all imagined as traditional Hindu eating habits:

My husband is vegetarian. He cannot eat in a plate because we eat meat in plates. So he uses metal plates similar to thali and I usually eat in normal plates. I never use this metal plate for meat. He has also kept two gilasa to drink water because he knows nobody will drink water from them...very rarely would he use ordinary plate or glass. 
Participants narrated preparing traditional natural medicines using traditional Indian utensils such as the Ounkri-Musal ${ }^{8}$. Knowledge about these therapies was transmitted from generation to generation. In some of the interviews, the use of ayurvedic ${ }^{9}$ medicine imported from India was also mentioned:

My grandparents, uncles and aunts used to use these. I saw that it was working. Some people say that they are not good but I do not think so. When I go to India I bring many ayurvedic medicines which I take. These days there are also juices made out of vegetables that are sold. I think they are good.

Blunt and Dowling (2006) found that material forms and their engendered practices can symbolise a home which is both material and imaginative. In this case, the constant process of forming and re-forming connections with an Indian ancestral root in daily mundane practices helped the Diaspora negotiate its identity between 'here' (Mauritius) and 'there' (India). On the other hand, in urban homes, these material forms had been replaced by modern appliances such as washing machines, electric and gas cookers, electric blenders and mixers amongst many others. In some homes, they were kept merely as traditional Hindu artefacts:

Even if I do not use them I like to keep them. They represent my culture, my Hindu religion but I think other religions use some of them too like karai, dekchi and thawa $^{10}$. I clean them all the time otherwise they will be spoilt. I show my children how to clean them. I will distribute these things among my children before I die.

Hence, while some members of the Diaspora had successfully recreated an imagined geography of India at home, others had embraced imaginative values of a more modern and Western-derived lifestyle. Said claimed that boundaries are often set up in the mind and leads to the unfolding of difference between spaces that is 'ours' and 'theirs'. Those living in urban regions were simultaneously endowing specific material dimensions with Hindu/Indian values while also demarcating the boundaries between these two spaces.

\section{The sacred space}

Participants often referred to their 'Hindu culture' instead of India as underlying the material cultures in their homes. This indicated strong religious and spiritualistic orientations in the Diaspora similar to their Indian counterparts. Their sacred space was 
populated by a panoply of religious icons, shrines and artefacts located inside the house indicating praying as a fundamental daily performance:

In the morning when I get up, I take a bath and perform my morning pooja. I also showed my son how to do this. How to do the aarti, how to put the incense sticks near the deities and what to say. If I show him, he will show his children.

Hindu scriptures such as the Bhagavad Gita ${ }^{11}$ and/or the Ramayana ${ }^{12}$ were considered must-haves in all homes despite the inability of participants to read them as they were written in Sanskrit (primary language of Hinduism):

Yes I have Bhagavad Gita but I have not read it. I used to watch Mahabharat ${ }^{13}$ serial on TV, so I know the story. Sometimes when we are fasting, we go to the temple and the pandit reads in Sanskrit and translates for us. The real Gita is in Sanskrit but most of us cannot read Sanskrit so it is hard. Now there are simple versions but the young people are not very interested.

Another noticeable religious artefact was the red piece of cloth tied to a bamboo stick which stood near a shrine representing Hanuman, a Hindu deity symbolising strength and protection. Also known as the Mahabirswami ${ }^{14}$, it was described as an essential marker of Hindu identity and its presence symbolised a Hindu home:

Anywhere you see this red flag you know that there is a Hindu living there. I change the flag every year. I normally call a pandit to do this as he knows the prayers. Every day I have to light the lamp before six in the evening. It is considered bad to leave the Mahabirswami in the dark. When I am not at home, my wife or my children do it. Sometimes the children forget and I shout at them as they should not forget.

Although India was rarely mentioned by participants, their sacred space and religious practices confirmed Vertovec's claim that the Indian Diaspora turns to religious objects and rituals in order to define its Hindu identity. Some participants gave profound importance to the source of these religious icons and artefacts:

All my deities are bought by a friend of mine who goes to India... she sells a lot of these when she comes back...I prefer the one from India itself as they are more beautiful and sometimes I ask her to bless them from there itself. 
Tolia-Kelly (2004) stated that sacred artefacts are locked in their connection with place. Echoing this, Coleman and Crang added that their movement is the "dissemination of place" $(2002,11)$ or "a piece of their place of origin" (della Dora 2009, 227). In this respect, the above shows that the Diaspora was unconsciously maintaining connection with India through its religion. Participants also narrated that their sacred space extended outside the home into temples and a major pilgrimage site called Ganga Talao (reading: lake representing river Ganges) or Grand Bassin (reading: French translation for big lake). This site is evidence how the Diaspora had successfully recreated imagined sacred geographies which have "iconic relation to sacred religious geographies" in India (Eisenlohr 2004, 86). It is built around a lake (Grand Bassin) to have the same geography as the river Ganges. The authenticity and sacredness of this site rests in the belief that water from the Ganges was poured into this lake when the first Indians came to Mauritius, hence paralleling it with the real Ganges in India. Every year thousands of pilgrims converge towards the lake on the great day of Shiva ${ }^{15}$ (Shivaratri) in the same way as Hindus living in India perform this religious ritual. This festival is one of the most celebrated Hindu diasporic moments in Mauritius. Eisenlohr stated "Grand Bassin/Ganga Talao and the Shivaratri pilgrimage are not just sites of Hindu religious practice, they embody a particular diasporic orientation towards a Hindu homeland evident in the attempt to replicate an Indian sacred geography in Mauritius.” $(2004,87)$

\section{Bhojpuri-our mother tongue}

Participants from rural regions used mostly Bhojpuri to communicate. Similar to religion, Bhojpuri was described as the prime indicator of their ethnicity and demarcated their familiar space:

I speak Bhojpuri at work... with my Hindu friends...I am more comfortable. They do not like it though. The Creoles tell us that we should speak Kreol but this is our mother tongue... we have grown up in it.

This strong attachment to Bhojpuri and somehow resistance to the local dialect (Kreol) and colonial languages had severe consequences for the following two participants:

When I went to school I could not speak Kreol as we only speak Bhojpuri at home. It was hard...the teachers had to learn Bhojpuri in order to teach us...but I tried 
and with time I learnt Kreol. My father was not happy that we were learning Kreol...he said that we were becoming like those $k a t w a^{3}$.

Could not do it...I left school at eleven. It was not easy to learn a new language and when you come home you speak something different...even Kreol I never spoke in those days. It is only after starting to work that I developed and learn Kreol.

On the other hand, despite having some basic understanding of Bhojpuri, urban participants had detached language to their ethnicity. They spoke Kreol instead. This became problematic when interregional marriages took place. For example, the following quote was from an urban woman who married in a rural region:

When I got married I did not speak Bhojpuri...I come from a town so we speak Kreol but here I had to learn as my mother and father-in-law only speak Bhojpuri...so I had to learn.

My in-laws don't understand anything but Bhojpuri!..they don't speak Kreol at all. It's a good thing that I speak Bhojpuri otherwise it could have been difficult... the children don't speak Bhojpuri so when they talk to their grandparents, I have to translate for them... you can't blame the children, things are changing but our old people don't understand this.

The language situation in the Diaspora is complex. For some, Bhojpuri is the prime indicator of their ethnicity while for others, it no longer is. Fishman (1989) claimed that religions cannot be separated from ethnicity same as it cannot be separated from language. This three-way link between language, religion and ethnicity varied not only between urban and rural regions, but also between different generations in the Diaspora. Below is a quote from a young participant who negotiates use of Bhojpuri based on the milieu and recipient:

Sometimes I answer her (grandmother) in Bhojpuri but sometimes in Kreol...she does not like but I try. When my parents are around I answer in Bhojpuri otherwise they get upset...I do speak Bhojpuri but it is more for fun sake. None of my friends speak it. If I speak to them they will laugh at me.

\footnotetext{
${ }^{3}$ Term used to identify the Creole and also denoting dirtiness
} 
From the above, it is evident that the Diaspora is constantly negotiating its ethnicity, religion and language use in a context where colonial ideological impulses are actively seeking control of both place and people. By retaining essential features, values and norms of a Hindu home, it was able to re-negotiate its identity through space and time. However, as this process extends to the workplace, the Diaspora's position becomes highly contested.

\section{Diaspora consciousness at work}

\section{Rural regions}

As mentioned earlier, participants narrated that they used Bhojpuri to communicate at work. Three types of speakers were identifiable: those who used the dialect to communicate with Hindus only, those who used it as a strategy for boundary maintenance, and those who spoke the dialect alongside Kreol and French. In the first case, Bhojpuri was considered the most acceptable mode of communication when addressing a Hindu whether it was in or outside work. This context-sensitive nature resonated with the findings of Panda and Gupta where Indians were found to shift their approach based on dimensions such as time, person and place. In this case, it was the person. Such speakers rarely spoke in Kreol to each other and hardly ever in French. In the second category, Bhojpuri was used to define the Diaspora's identity and demarcate the group's boundary:

[They] think they are better because they speak French... [They] are gran noir ${ }^{4}$ So we do the same, we speak Bhojpuri...there is no shame at all.

I prefer to speak to Hindus at work. The others are not like us...they do not understand our culture...I have mostly Hindu friends...they are like family.

Unlike Sinha's findings that Indians had a preference for personalised relationships, these quotes also denote hostility towards the Other unfolding into a space that is 'ours' and 'theirs'. The third case included participants from rural regions who had a wider speech repertoire and mastered both French and English. They occupied better positions and were more engaged with other ethnic groups.

\footnotetext{
${ }^{4}$ Arrogant and of high status
} 
However, their language potential was perceived negatively and mocked by employees from the above two groups. The use of French in particular was constantly referred to as being gran noir and derogatory comments were inevitable. Below is a quote from a participant who works as a waiter and who has good French speaking skills:

At first it was difficult to speak French properly but with practice I succeeded but I still feel uncomfortable to speak it when any of my friends are around. If they hear, they will make fun of me...I know that whenever I speak French I look around to see if anyone else is around. Most waiters speak French well but very few of them are Hindu. Most are Creoles and for them they even speak French with each other sometimes. Kreol and French are very similar so they do not have to feel awkward but for us Bhojpuri is very different to French.

The intra-ethnic communication and bonding resulting from the use of Bhojpuri lead to the formation of Hindu cliques. The saliency attached to language and ethnicity in the Diaspora made their work behaviour highly personalised. Collectivist behaviours had previously been linked with lack of education and less developed contexts (see: Mishra 1994), however in this case it was also about the role-bounded nature of the Diaspora. The desire to be embedded in their groups (Hindu cliques) pushes even those who had the skills to speak French and Kreol to surrender to the expectations of the group. Preference for intra-ethnic bonding and in-group role bounded behaviours, lead them to socialise mainly with Hindus despite working with other ethnic groups:

I make friends with everyone but I have more Hindu friends...I think it is normal in Mauritius to have more friends from the same religion...but I don't mind Creole, Chinese... anything.

There are some Creole women in my team...we talk but [they] are not really good friends...I feel more at ease with Hindus as they understand the things we do...we share food at work and if it is Creole, then I cannot eat their food.

The non-existence of a language policy at work resulted in the proliferation of Bhojpuri in many rural hotels. This was perceived as a form of resistance to the norms of the industry and was strongly criticised by management:

We understand that this is their language but at work it does not help us or them. Here we expect people to speak Kreol or French but if they refuse then it is in their 
own disadvantage. They cannot talk to guests and so cannot get the nice jobs. They want this, it is not our fault.

Both managers were Creoles and although all interviews were conducted in Kreol, they tended to answer eloquently in French. Several conversations also contained both Kreol and French words. Overall, French was widely spoken by most management level employees in the hotels. While it may be symbolic of status denoting a higher level of education as well as a position of command and authority in the organisation, they also spoke in Kreol to lower level employees. A hierarchisation of language becomes clearly discernible as the managers relate about their conversations with other employees:

We always use French when talking to other managers. It is normal here. Anyway they will always start the conversation in French so we continue in the same language. But when we are among ourselves we speak both French and Kreol.

When I talk to other employees I use Kreol because they don't speak French...or maybe they understand but they don't speak it. It is better to speak in Kreol to them. It will look strange if I use French with my waiters...they will laugh at me!

None of them reported speaking Bhojpuri at work. The coexistence of French, Kreol and Bhojpuri has also lead to a hierarchisation of language at work with French being considered a language of high status, Kreol described as a mode of communication but used mainly in informal and routine conversations and lastly Bhojpuri as a low status and ethnic dialect. The Diaspora's resistance to the higher status languages threatened its position, pushed it more towards low skilled jobs and lessened its prospects for upward mobility at work.

\section{Urban regions}

The urban Diaspora has evolved. Its networking pattern was mixed and language repertoire was wide. It occupied better positions. Despite holding on to its Hindu values at home, the workplace was where multiple and mixed encounters took place. However, amid these signs of mixing, speaking French and/or English was work related and still perceived as gran noir: 
Yes we [have to speak] French because this is the hotel industry and we have many clients who speak French...but there are some people who speak it even when they are talking to each other. I think they want to show that they are superior...for example those who work in offices, they hardly speak Kreol. Many Creoles with good jobs also speak French all the time. I only speak French when needed otherwise it is Kreol. But sometimes I have some Indian friends who want to be like them and you find them speak French many times.

Hence, in urban regions, the Diaspora had embraced multilingualism for its capital endorsement (acquiring a good job), and/or its status. For those aspired by both, the findings show that certain barriers remain hard to overcome:

I speak French because it is part of my work but my friends make fun of me. When you speak Kreol, some words may slip or you may pronounce something wrongly not because you don't know but it is just the tongue...but others will make fun and sometimes I just stop. Some people will never change. They will stay barbar $^{5}$. Because they cannot speak, they laugh at others.

This quote re-confirms the role-bounded collectivist nature of the Diaspora. The traditional discouraging to move away from the group is salient and presents several challenges for many. The quote below is from a member of the Diaspora who has supervisory role in one of the hotels. His position of authority required him to choose between his role in the group and his role as a supervisor:

No we don't speak Bhojpuri at all...it is not allowed...well not that it is not allowed but why would you speak in Bhojpuri when everyone understands Kreol. Some people speak Bhojpuri with each other but as a supervisor I can't do this even if I know the language. People will think that I am racists and I am protecting my type of people.

A context-sensitive behaviour can be clearly identified in this participant's conversation. Despite being aware that there no regulations against speaking Bhojpuri, his position pushes him to shift his approach and retrieve from the role-bound collectivist nature of the group.

\footnotetext{
${ }^{5}$ Barbarian.
} 


\section{Discussions}

The Indian Diaspora in Mauritius is a typical example of a hybrid community that has successfully deployed partial culture from its Indian roots in order to sustain its identity in foreign land. Through its home-making practices, members have created a space symbolising Hindu-ness and/or Indian-ness. Material cultures have formed the bridge between colonialism and cultural identity as Bhabha noted. From the findings much of their Diaspora consciousness was manifested through religion confirming Vertovec's claims. Through rituals, they had created both sensuous and emotional geographies (Hannam et al. 2006). These could be observed in the feelings expressed when the Diaspora related about them. Those living in rural regions had constructed a highly traditional version of a Hindu home symbolising their solidarity towards their religion and their roots. The continuous use of Bhojpuri while rejecting French, English and Kreol was also a marker of cultural identity. Their performative actions showed an obvious staging of cultural difference via their home-making practices, religious beliefs and networking patterns. To Bhabha and in this case, the culture that the Diaspora developed on new soil (Mauritius) was highly sensitized and held an overly traditional view of the parent culture (India). Through these persistent and renewed acts of solidarity as mundane as they may seem, the Diaspora was making the homogenising intent of the pedagogical inappropriate and unrealisable thus simultaneously and consciously resisting both Mauritian identity and colonial authority.

However, the findings also reveal that cultural purity never quite existed. Infiltration of colonial and Western values, ethos and symbols had become inevitable as Mauritius developed. The present performative temporality of the Diaspora also showed commercial actions signifying an improved socio-economic position. In both rural and urban regions, the Diaspora had appropriated Western capital goods. For instance, their homes were also populated by items which had no association with the traditional Indian way of life they imagined. These were necessary to show an improved socioeconomic position and to make their homes look modern. In rural regions, many of these remained unused and sometimes unpacked to maintain longevity. It was a form of mimicry which highlighted an acknowledgement of a difference in status based on material appropriation thus forcing the Diaspora to adopt a Western lifestyle but where the outcome was only "a subject of a difference, that is almost the same, but not quite 
the same" as stated by Bhabha. Despite appropriation of these goods, the Diaspora's bond with its ethnicity and religion reversed the effects of the colonist disavowal and estranged the basis of its authority to create a state of intentional hybridity.

The canny process of estranging colonial authority is extended with the continued use of Bhojpuri at work. The rejection of French as a mode of communication and the stereotypical term gran noir being used on several occasions disrupts the authority of colonial discourse. As put forward by Haynes and Prakash (2001), a worker's action can be categorised as a form of resistance depending upon the material and symbolic context and consequences of his action. In this case, rejection of French, an important language to be productive in the industry, represented not only a form of resistance to management control but also disruptive behaviour and hindrance to good customer service. Concomitantly, it lead to ethnic networking which affected group dynamics at work. However, the findings also showed evidence of workers who were willing to speak French but whose actions were mocked by others. The inner fear of being laughed at and the feeling of discomfort both characterised the fissures and cracks within this ambivalent space where the Diaspora is. Mocking the use of French can here be seen as a form of conscious resistance by the workers while at the same time failure by colonial discourse to maintain hegemonic control over them. However, the authority of French as a high status and valorised language was apparent among individuals occupying management level positions. Despite being small in number, they had successfully established a hierarchisation of language whereby French had the highest status and was preferred over Kreol and Bhojpuri. Phillipson (1996) calls this linguistic imperialism and it implications for the Diaspora in the workplace is drastic. Their limited use of French and Kreol (in rural regions) can cause unequal access to organisational resources. This in turn may hinder the Diaspora's ability to move up the organisational ladder.

Findings also revealed the existence of hybrid spaces within which the Diaspora was able to hold different identities together. In urban regions, acquiring Western material forms had become part of creating an imagined geography of a modern household while also maintaining religious and cultural values. Moreover, those living and working in urban regions were able to coexist with other ethnic groups both at work and in the wider community while also retaining partial culture from their ancestral 
roots. At work, they were receptive to speaking French and/or Kreol. However, complete hegemonic control was yet to be achieved as they remained sincere to their traditional religious values and still engaged in intra-ethnic bonding. Moreover given the choice, they would speak Kreol rather than French. This type of intentional hybridity is evidence that even in urban regions, assimilation was never complete. By doing so, these workers' behaviours had created a space which was highly contested and ambivalent as they negotiate their identities on a regular basis. This hybrid space, as Loomba puts it, offers potential for resistance and simultaneously indicates the effects of the dominant force and resistance to it as stated by Yousfi (2013).

There is always ambivalence at the site of colonial dominance and the quotes from the participants enunciate this. The continual fluctuation between wanting one thing and its opposite demarcate a blurring of boundaries between the Diaspora and the remainder Mauritian society. In a colonial context, ambivalence occurs when authority becomes hybridized and finds itself layered against other cultures. In this case, colonial culture was simultaneously oppressive and emancipatory. The oppressiveness nature is discernible by the way Bhojpuri is undermined as a language vis-à-vis the dominant colonial language. Its cultural bearing for the Diaspora is ignored and undervalued whilst on the other hand, being able to speak French gives status and recognition. The desire of the Diaspora to maintain its traditional values and language is somehow detested by colonial discourse but it works in subtle ways to punish the former such as its lower job mobility compared to others.

\section{Concluding remarks}

This paper makes an important contribution to our understanding of Indian culture in organisations and this special issue. Using the case of the Indian Diaspora emerging from the first wave of Indian emigration, I looked at a population which, in the turmoil of Information Technology and engineering outsourcing, is rather under-represented in the literature. Moreover, I have demonstrated that the behaviours of people of Indian origin is largely influenced by their religion and language. By considering the hermeneutics of home, it was possible to see how Diaspora consciousness manifested itself through these two cultural dimensions and thereafter culminate into nontraditional forms of resistance both at home and at work. This approach was useful in order to capture the way the Diaspora engages with unequal power relations on the new 
land. However, this study concerns an Indian Diaspora with a different history and contextual dynamics to the remaining Indian diasporic community in the world today. Therefore, the applicability of its findings is mainly confined to Mauritius but could also appear relevant to other postcolonial contexts where people of Indian origin hold similar histories and demographics. However, the general findings on the role religion and language in situating the Diaspora away from home should not be overlooked by current and future research on the 'new' Indian Diaspora. Both dimensions rarely appear in existing research on Indian culture in organisations despite evidence that they represent fundamental characteristics of this population. By integrating both in my research, I have demonstrated that future research attempting to understand and situate this group in the organisational context, should emphasise both religion and language as relevant determinants of behaviour. This will ultimately require a shift towards more focussed, fine grained qualitative methods that cut across multiple locations as it was the case in this paper.

Furthermore, by drawing from postcolonial theory and borrowing Bhabha's concepts of mimicry, ambivalence and hybridity, I have demonstrated that theories which describe the nation as a surrogate of culture can no longer capture the realities of people who are on the move. As vessels of culture, people take away with them culture that relates to their roots as they relocate to foreign land, yet the purity of these cultural forms is continuously challenged by the new context. Bhabha's conceptual framework allows culture to be seen as an ever-moving dimension, continuously resisting and negotiating its space in the country of the Other while also embracing new forms. This theory gives scope to an improved understanding of the situation of those members of the Indian Diaspora who are currently living away from India but above all, it can help identify non-traditional forms of resistance in organisations and in the wider society. Employee cross-cultural dynamics reap enormous benefits as well as dysfunctionalities in organisations. Thus, an understanding of non-traditional forms of resistance could help practitioners put in place mechanisms that identify integration-related bottlenecks faced by diasporic communities who are working away from home. Many of them may never return to their country of origin, including the Indian Diaspora:

The banyan tree has thrust down roots... and somehow drawn sustenance from diverse unpromising conditions. Yet the banyan tree itself has changed, its similarity to the original growth is still there, but it has changed 
in response to its different environment. For those who leave South Asia, in almost every case, there is no going back (Tinker 1977: 19).

\section{References}

Anwar, A; and M. Mughal. 2013. "The role of diaspora in attracting Indian outward FDI." International Journal of Social Economics 40 (11):944-955.

Ashcroft, B; G. Griffiths; and H. Tiffin, eds. 1995. The post-colonial studies reader. London: Routledge.

Bakhtin, M. 1981. The dialogic imagination. Texas: University of Texas Press.

Beine, M; F. Docquier; and C. Ozden. 2011. "Diaspora effects in international migration: key questions and methodological issues." World Bank Policy Research Working Paper Series.

Beine, M; and S. Salomone. 2013. "Network Effects in International Migration: Education versus Gender." The Scandinavian journal of economics 115 (2):354380.

Bhabha, H.K. 1990. Nation and Narration. London: Routledge.

Bhabha, H.K. 1994. The location of culture. Routledge: London.

Bhabha, H.K. 1996. "Culture's in-between." Questions of cultural identity:53-60.

Bhabha, H.K. 1984. "Of mimicry and man: the ambivalence of colonial discourse." October: $125-133$.

Bhatia, S; and A. Ram. 2009. "Theorizing identity in transnational and Diaspora cultures: A critical approach to acculturation". International journal of intercultural Relations 33:140-149.

Bissoonauth, A. 2011. "Language shift and maintenance in multilingual Mauritius: the case of Indian ancestral languages." Journal of Multilingual and Multicultural Development 32 (5):421-434.

Blunt, A; and R. Dowling. 2006: Home. London: Routledge.

Boswell, R. 2005. "Unravelling Le Malaise Creole: Hybridity and Marginalisation in Mauritius". Global Studies in Culture and Power 12:195-221

Sinha, J.B.P; and R.N. Kanungo. 1997. "Context sensitivity and balancing in Indian organizational behaviour." International Journal of Psychology 32 (2):93-106.

Bryman, A. 2004. Social Research Methods. Oxford: Oxford University Press.

Buckley, P; J.N. Forsans; and S. Munjal. 2012. "Host-home country linkages and host- 
home country specific advantages as determinants of foreign acquisitions by Indian firms." International Business Review 21 (5):878-890.

Callikan, S. 2001. “Communalisme et vie poltique: La question de la citoyennete a l'ile Maurice" [Communalism and politics: The question of citizenship in Mauritius]. Master's Dissertation; University of Paris.

Caroll, B.W; and T. Caroll. 2000. "Accommodating ethnic diversity in a modernizing democratic state: theory and practice in the case of Mauritius". Ethnic and Racial Studies 23(1):120-142

Carter, M; and K. Torabully. 2002. Coolitude: An Anthology of the Indian Labour Diaspora. London: British Library Cataloguing.

Chand, M. 2012. "Diasporas, migration, and trade: the Indian diaspora in North America." Journal of Enterprising Communities: People and Places in the Global Economy 6 (4):383-396.

Cole, N; and K. Nesbeth. 2014. "Why do international assignments fail? The expatriate families speak." International Studies of Management and Organization 44(3): (In press).

Coleman, S; and M. Crang. 2002. Tourism: between place and performance. Berghahn Books.

Contractor, F; J.V. Kumar; and C. Dhanaraj. 2015. "Leveraging India: Global Interconnectedness and Locational Competitive Advantage." Management International Review 55 (2):159-179.

Deerpalsing, S. 2002. Desi Roots: Diaspora Looking Back. Moka, Mauritius: Mahatma Gandhi Institute

della Dora, V. 2009. “Taking Sacred Space out of Place: From Mount Sinai to Mount Getty through Travelling Icons". Mobilities 4(2):225-248.

Dhume, S. 2002. "Bangalore to Silicon Valley and Back". In India Briefing: Quickening the Pace of Change, edited by Alyssa Ayres and Philip Oldenbur. Armonk, 312-322, NY:M.E.Sharpe

Dickinson, J. 2015. "Articulating an Indian diaspora in South Africa: The Consulate General of India, diaspora associations and practices of collaboration." Geoforum 61:79-89.

Dudley, S. 2011. "Feeling at home: Producing and consuming things in Karenni refugee camps on the Thai-Burma border." Population, Space and Place 17 (6):742-755. 
Eisenlohr, P. 2004. "Register levels of ethno-national purity: The ethnicization of language and community in Mauritius". Language in Society 33(5): 59-80.

Eisenlohr, P. 2010. "Religious Media, Devotional Islam, and the Morality of Ethnic Pluralism in Mauritius". World Development 39(2):261-269.

Eisenlohr, P. 2011. "Media authenticity and authority in Mauritius: On the mediality of language in religion." Language \& Communication 31 (3):266-273.

Eisenlohr, P. 2013. "Mediality and materiality in religious performance: Religion as heritage in Mauritius." Material Religion: The Journal of Objects, Art and Belief 9 (3):328-348.

Eriksen, T.H. 1990. "Linguistic diversity and the quest for national diversity: the case of Mauritius". Ethnic and Racial Studies13 (1):1-24.

Eriksen, T.H. 1994. "Nationalism, Mauritian Style: Cultural Unity and Ethnic Diversity". Comparative Studies in Society and History 36(3):549-574.

Fishman, J.A. 1989. Language \& Ethnicity in Minority Sociolinguistic Perspective. Clevedon: Multilingual Matters.

Hannam, K; M. Sheller; and J. Urry. 2006. "Mobilities, Immobilities and Moorings". Mobilities 1(1):1-22.

Haynes, D; and G. Prakash. 1991. Introduction: The entanglement of power and resistance. In Contesting Power, edited by Haynes, D and G. Prakash, 1-22. Berkeley; CA: University of Californa Press.

Hofstede, G. 1980. Culture's Consequences: International Differences in Work-related Values. London: Sage.

Hiralal, K. 2014. "Women and migration in South Africa: historical and literary perspectives." South Asian Diaspora 6 (1):63-75.

Hirschmann, D. 2014. "'Rendering'Ethnicity in the Mauritius National Assembly: Continuities and Codes." Parliamentary Affairs: gsu010.

Hollup, O. 1994. "The disintegration of caste and changing concepts of Indian ethnic identity in Mauritius". Ethnology 33(4):297-316.

Imas, J. M; and A. Weston. 2012. "From Harare to Rio de Janeiro: Kukiya-Favela Organisation of the Excluded". Organisation 19 (2):205-227.

Jahangeer-Chojoo, A. 2010. "From Minority to Mainstream Politics: The Case of Mauritian Muslims". Journal of Sociological Science 25 (1-2-3):121-133. Jain, Ravindra K. 2010. Nation, Diaspora, Trans-nation : Reflections from India. 
Abington: Routledge. http://strath.eblib.com/patron/FullRecord.aspx?p=692413.

Javorcik, B; S. Çağlar Özden; M. Spatareanu; and C. Neagu. 2011. "Migrant networks and foreign direct investment." Journal of Development Economics 94 (2):231241.

Kalonaityte, V. 2010. "The case of vanishing borders: theorizing diversity management as internal border control." Organization 17 (1):31-52.

Kapur, D. 2001. "Diasporas and Technology Transfer". Journal of Human Development $2(2): 265-86$

Kapur, D. 2014. "Political effects of international migration." Annual Review of Political Science 17:479-502.

Kasenally, R. 2011. "Mauritius: paradise reconsidered." Journal of Democracy 22 (2):160-169.

Knoblauch, H. 2009. "Videography: Focussed ethnography and video-analysis". In Video Analysis: Methodology and Methods: Qualitative Audiovisual Data Analysis in Sociology, edited by Knoblauch, H., et al. Frankfurt: Lang.

Kumar, P. 2012. "Place of subcaste (jati) identity in the discourse on caste: examination of caste in the diaspora." South Asian Diaspora 4 (2):215-228.

Lal, B.V. 2015. "The World becomes Stranger, the Pattern More Complicated': Culture, Identity and the Indo-Fijian Experience1." Indian Diaspora: SocioCultural and Religious Worlds: 52.

Lazarova, M., M. Westman; and M.A. Shaffer. 2010. "Elucidating the positive side of the work-family interface on international assignments: a model of expatriate work and family performance." Academy of Management Review 35(1):93-117.

Lee, M. 2013. "Home and Away: Female transnational professionals and their construction of home.” Paper presented at 108th American Sociological Association Annual Conference, 2013.

Loomba, A. 1998. Colonialism/postcolonialism. London: Routledge.

Mathur, Raj. 2012. "Party cooperation and the electoral system in Mauritius." In Electoral Systems in Divided Societies:the Fiji Constitution Review, edited by Lal, B.V; and P. Larmour, 135-146. Canberra: ANU E Press.

Miles, W.F.S. 1999. “The Creole Malaise in Mauritius”. African Affairs 98(391):211228.

Mir, A.R; A. Mir; and P. Upadhyaya. 2003. "Toward a Postcolonial Reading of 
Organisational Control”. In Postcolonial theory and organizational analysis: A critical engagement, edited by Prasad, A. 45-73, Palgrave: Macmillan.

Mishra, R. C. 1994. "Individualist and collectivist orientations across generations.” In Individualism and Collectivism: Theory, Method, and Applications, edited by Kim, U; H. C. Triandis; C. Kagitcibasi; S.C. Choi; and 0. Yoon, 225-238. Thousand Oaks: Sage.

Mitchell, J. P. 2007. "A fourth critic of the Enlightenment: Michel de Certeau and the ethnography of subjectivity”. Social Anthropology 15(1):89-106.

Mulloo, A. 2007. Hinduism and the Indian Diaspora. New Delhi: Richa Prakashan

Owodally, A; and A. Mooznah. 2011. "Multilingual language and literacy practices and social identities in Sunni madrassahs in Mauritius: A case study." Reading Research Quarterly 46 (2):134-155.

Özkazanç-Pan, B. 2008. "International management research meets "the rest of the world"." Academy of Management Review 33 (4):964-974.

Pal, M; and M. Dutta. 2008. "Theorising resistance in a global context". In.Communication Yearbook, edited by Beck C, 41-87, New York: Routledge.

Panda, A; and R.K. Gupta. 2012. "Deconstructing context-sensitive nature of Indians'behaviour: a preliminary attempt to develop a taxonomy for three work contexts." International Journal of Indian Culture and Business Management 5 (6):696-733.

Pande, A. 2014. "The role of Indian Diaspora in the development of the Indian IT industry." Diaspora Studies 7 (2):121-129.

Pandey, A., A. Aggarwal; R. Devane; and Y. Kuznetsov. 2004. India's transformation to knowledge-based economy-evolving role of the Indian diaspora. Draft report. World Bank: Washington, DC.

Phillipson, R. 1996. “Linguistic imperialism: African perspectives”. ELT Journal 50:160-167.

Prasad, A; and P. Prasad. 2001. "(Un) willing to resist? the discursive production of local workplace opposition*." Studies in Cultures, Organizations and Societies 7 (1):105-125.

Prasad, A. 2003. Postcolonial theory and organizational analysis: A critical engagement: Palgrave Macmillan.

Prasad, A. 2012. Against the grain: advances in postcolonial organization studies. Vol. 
28: Copenhagen Business School Press DK.

Premdas, R R. 2011. "Identity, ethnicity, and the Caribbean homeland in an era of globalization." Social Identities 17 (6):811-832.

Raghunandan, K. 2012. "Hyphenated identities: Negotiating 'Indianness' and being Indo-Trinidadian. Caribbean Review of Gender Studies 6:1-19

Raj, A. 2012. "The Indian Diaspora in North America: The Role of Networks and Associations." Diaspora Studies 5 (2):107-123.

Rajah-Carrim, A. 2005. "Language use and attitudes in Mauritius based on the 2000 Population Census". Journal of Multilingual and Multicultural Development 26 (4)

Ralph, D; and A. L. Staeheli. 2011. "Home and Migration: Mobilities, Belongings and Identities." Geography Compass 5 (7):517-530.

Rohatgi, R. 2013. "Postcolonial Hindi Translation in Mauritius: The Case of Kalpana Lalji's Amargeet." Matatu-Journal for African Culture and Society 41 (1):125135.

Safran, W; A. Sahoo; and L.V. Brij. 2009. Transnational Migrations : The Indian Diaspora. London: Routledge. http://strath.eblib.com/patron/FullRecord.aspx?p=1487217.

Said, E. (1977). Orientalism. New York: Vintage Books, http://www.odsg.org/Said_Edward(1977)_Orientalism.pdf

Sambajee, P. 2011. "Multiple Mobilities in the Hotel Industry: a case study of the North Indian Diaspora in Mauritius.” PhD Dissertation; University of Sunderland.

Saxenian, A. 1999. Silicon Valley's new immigrant entrepreneurs. Vol. 32: Public Policy Institute of California: San Francisco.

Scott, J.C. 1985. Weapons of the weak: Everyday forms of peasant resistance. New Haven: Yale University Press

Sen, N.C. 2014. "The Creation of Diaspora and Its Historical Significance." In Global Diasporas and Development, 387-399. Springer.

Sinha, B.L. 2014. "Social movements of the historical Indian Diaspora in South Africa: binding the 'home'and 'homeland'creatively?" Diaspora Studies 7 (1):1-17.

Sinha, J.B.P; and D. Sinha. 1990. "Role of social values in Indian organizations." International Journal of Psychology 25 (3-6):705-714.

Sinha, J.B.P. 2000. "Towards indigenization of psychology in India". Psychological 
Studies 45(1-2):3-13

Sinha, J.B.P. 2002. "A cultural frame for understanding organisational behaviour". Pschology and Developing Societies 14 (1):155-166

Sinha, J.B.P. 2004. Multinationals in India Managing the Interfaces of Cultures. New Delhi: Sage.

Sinha, J.B.P; and A. Pandey. 2007. Indians' mindsets and the conditions that evoke them". National Academy of Psychology 52(1):1-13.

Spivak, G.C. 1999. A critique of postcolonial reason: Toward a history of the vanishing present. Cambridge, MA: Harvard University Press.

Spivak, G.C. 2008. Other Asias. Malden, MA: Blackwell.

Srivastava, D.K., and M. Panday. 2012. "Dimensions of Indian expatriate adjustment in the USA: an exploratory study." Competitiveness Review 22 (4):320-328.

Strauss, A; J. Corbin. 2008. Basics of qualitative research: Techniques and procedures for developing grounded theory: Sage Publications, Incorporated

Suri, G.S; and P.Y. Abbott. 2013. "IT Cultural Enclaves and Social Change: The Interplay between Indian Cultural values and Western Ways of Working in an Indian IT Organization." Information Technology for Development 19 (3):193214.

Tejada, G; U. Bhattacharya; B. Khadria; and C. Kuptsch. 2013. Migration, Scientific Diasporas and Development: Impact of Skilled Return Migration on Development in India. Cahier de la Coopération No. 8, Cooperation and Development Center, EPFL.

The GlOBE STUDY (Gupta, V; G. Surie; M, Javidan; and J.Chhokar). 2002. "South Asian Cluster: Where the old meets the new?" Journal of World Business 37(1):10-27

Tinker, H. 1977. "Between Africa, Asia and Europe: Mauritius: Cultural Marginalism and Political Control". African Affairs 76(304): 321-338.

Tolia-Kelly, D.P. 2004. "Materializing post-colonial geographies: examining the textural landscapes of migration in the South Asian home". Geoforum 35:675688

Tölölyan, K. 2010. "Beyond the Homeland: From Exilic Nationalism to Diasporic Transnationalism." In The Call of the Homeland, edited by Gal, A.S; A.S. Leoussi; and A.D. Smith, 27-46. Brill: Leiden 
Tseung-Wong, C.Ng; and M. Verkuyten. 2015. "Multiculturalism, Mauritian Style Cultural Diversity, Belonging, and a Secular State." American Behavioral Scientist, DOI:10.1177/0002764214566498

Tung, R.L; F.L.H. Chung; and P. Enderwick. 2011. "Immigrant effects and international business activity: an overview." Journal of Asia Business Studies 5 (1):6-22.

Vaaler, P.M. 2013. "Diaspora concentration and the venture investment impact of remittances." Journal of International Management 19 (1):26-46.

Vemuri, S R. 2014. "Formation of Diaspora Entrepreneurs". ZenTra Working Paper in Transnational Studies No. 41/2014, http://dx.doi.org/10.2139/ssrn.2519432

Vertovec, S. 2000. The Hindu Diaspora: Comparative patterns. London: Routledge

Weller, S.C., and A. K. Romney. 1988. Systematic data collection. Vol. 10: Sage.

Ybema, S., D. Yanow; H. Wels; and F. Kamsteeg, eds. 2009. Organizational

Ethnography: Studying the Complexities of Everyday Life. London: Sage.

Young, R.J.C. 1995. Colonial desire, Hybridity in theory, culture and race. London: Routledge.

Young, R.J.C. 2008. Postcolonialism: An historical introduction. Oxford: Blackwell

Yousfi, H. 2013. "Rethinking Hybridity in Postcolonial Contexts: What Changes and What Persists? The Tunisian case of Poulina's managers." Organization Studies 35(3):393-421.

\footnotetext{
${ }^{1}$ Water carrying vessel usually made up of copper or stainless steel used in prayers

${ }^{2}$ Stainless steel plate

${ }^{3}$ Prayer for the Goddess Durga

${ }^{4}$ It is a ritual of worship in the Hindu religion in which camphor or lamps are lit and offered to deities

${ }^{5}$ Indian cooking pan with lid made from aluminium

${ }^{6}$ Traditional cast iron pan

${ }^{7}$ Mug made of steel or copper
} 
${ }^{8}$ Traditional spice grinder

${ }^{9}$ A word used for the ancient Indian medicinal system

${ }^{10}$ Chapati pan

${ }^{11}$ Hindu Holy scriptures

${ }^{12}$ Hindu Holy scriptures

${ }^{13}$ Religious TV serial based on Sanskrit epic

${ }^{14}$ It is a small temple that is found in the front yard of all Hindu homes and it contains a statue of Lord Hanuman

${ }^{15}$ Hindu God symbolising Creator of the Universe 